\title{
Örgütsel Adalet ve Örgütsel Özdeşleşmeye Yönelik Kırgızistan Türkiye Manas Üniversitesindeki Personelin Tutumlarının Belirlenmesi
}

Öz

Bu araştırmada örgütsel adalet ve örgütsel özdeşleşme arasındaki ilişkiyi ve örgütsel adaletin boyutlart ile örgütsel özdeşleşme arasındaki ilişkiyi incelemek amaçlanmıştır. Bununla birlikte örgütsel adalet ve boyutları ile örgütsel özdeşleşmenin demografik değişkenler açısından farklılaşıp farklılaşmadı̆̆g test edilmiştir. Kirgizistan-Türkiye Manas Üniversitesi'ndeki 110 akademik ve idari personel, araştırmanın örneklemini oluşturmaktadır. Çalışmada kolayda örnekleme tekniğiyle veriler toplanmıştır. Niehoff ve Moorman (1993) tarafindan geliştirilen Örgütsel Adalet Ölçeği ve Mael ve Ashforth (1992) tarafindan geliştirilen Örgütsel Özdeşleşme Ölçeğinden yararlanılmıştır. Araştırmada cinsiyet, yaş, eğitim düzeyi, unvan, kıdem, idari görevin olup olmamasına göre örgütsel adalet ve örgütsel adaletin boyutlart ile örgütsel özdeşleşmeye yönelik farklllık analizleri yapılmıştır. Cinsiyete göre örgütsel adalet, dağıtımsal adalet ve işlemsel adalet algılarının farklılaştığ tespit edilmiştir. Yaş ve kıdeme göre işlemsel adalet algılarında ve unvana göre örgütsel adalet ve boyutlarında farklllık söz konusudur. Eğitim düzeyi ve idari görevin olup olmamasına göre örgütsel özdeşleşme düzeylerinin farklllaştığl görülmüş̧ür. Son olarak örgütsel adalet, işlemsel adalet ve etkileşimsel adalet ile örgütsel özdeşleşme arasında anlamlı bir ilişsi bulunamazken, dağıtımsal adalet ve örgütsel özdeşleşme arasında anlamlı bir ilişki bulunmuştur.
\end{abstract}

Anahtar Kelimeler: Örgütsel adalet, örgütsel özdeşleşme, akademik personel, idari personel, Kırgızistan Türkiye Manas Üniversitesi

\section{Determination of Organizational Justice and Organizational Identification Attitudes of Staff at Kyrgyz Turkish Manas University}

\begin{abstract}
In this study, it is aimed to examine the relationship between organizational justice and organizational identification and the relationship between dimensions of organizational justice and organizational identification. In addition, it was tested whether organizational justice and its dimensions and organizational identification differ in terms of demographic variables. 110 academic and administrative staff at Kyrgyz Turkish Manas University constitute the sample of the research. In the study, data were collected by convenience sampling technique. Organizational Justice Scale was used developed by Niehoff and Moorman (1993) and Organizational Identification Scale was used developed by Mael and Ashforth (1992). In the research, a difference analysis was made for the dimensions of organizational justice and organizational justice and organizational identification according to gender, age, education level, title, seniority, and whether there is an administrative task. There are differences in procedural justice perceptions according to age and seniority, and organizational justice and dimensions according to title. Finally, there was no significant relationship between organizational justice, procedural justice and interactional justice and organizational identification, while a significant relationship was found between distributive justice and organizational identification.
\end{abstract}

Keywords: Organizational justice, organizational identification, academic staff, administrative staff, Kyrgyz Turkish Manas University

\footnotetext{
*ORCID Prof. Dr., Pamukkale Üniversitesi, İ̈BF, İşletme Bölümü, cserinkan@pau.edu.tr

**ORCID Doktora Öğrencisi, Pamukkale Üniversitesi, SBE, İşletme Bölümü, mmenguloglu14@posta.pau.edu.tr
} 


\section{Extended Abstract}

In this study, the relationship between organizational justice and organizational identification was examined. First, information was given by scanning the literature on organizational justice and organizational identification. Concepts have been defined. Its importance in terms of organizations has been examined. In the following, the aim of the research was stated. The scales used in the research method are explained. The Organizational Justice Scale developed by Niehoff and Moorman (1993) and the Organizational Identification Scale developed by Mael and Ashforth (1992) were used. The reliability of the scales was tested with the Cronbach's Alpha reliability coefficient. Accordingly, the organizational justice scale and organizational identification scale used in the research were found to be reliable. Demographic characteristics of the academic and administrative staff participating in the research are given. Frequency analysis was used here.

The model and hypotheses of the research were formed and explained. From this point of view, hypotheses were tested. The presence of gender and administrative duty was analyzed by t-test. The ttest is used to analyze two-group independent variables. Age, education level, seniority and title variables were analyzed by Anova analysis. Anova analysis is used to test independent variables with more than two groups. Thus, it was tested whether organizational justice, dimensions of organizational justice and organizational identification differed according to gender, presence of administrative duties, age, education level, seniority and title. The results obtained are:

- Perceptions of organizational justice, distributive justice and procedural justice differ according to gender.

- The perception of procedural justice differs according to age and seniority.

- Perceptions of organizational justice, distributive justice, procedural justice and interactional justice differ according to the title.

- The level of organizational identification differs according to the level of education and whether there is an administrative task.

Finally, the relationship between organizational justice and dimensions of organizational justice and organizational identification was examined. The relationship between the variables was tested by correlation analysis. The results obtained are:

- There is no statistically significant relationship between organizational justice, procedural justice and interactional justice and organizational identification.

- A statistically significant relationship was found between distributive justice and organizational identification.

The results of the study were compared with the results obtained in previous studies. It has been understood that these results are similar to the studies in the literature. Within the scope of these results, recommendations were given to researchers and managers. Points to be considered in subsequent studies were emphasized. This study is expected to contribute to the literature. 


\section{Giriş}

Adalet kavramı ilk çağlardan beri insanlığın üzerinde önemle durduğu bir kavramdır. Günümüzde ise önemini korumakta ve araştırmacıların dikkatini çekmeye devam etmektedir. Örgütlerin güncel problemleri incelendiğinde temel olarak adalet ile ilgili problemlerle karşılaşılmaktadır. Bireylerin veya yöneticilerin işyerindeki davranış ve tutumları, genel olarak örgütsel adalet algılarından etkilenmekte ve beraberinde farklı davranış ve tutumların gelişmesine yol açmaktadır. Çalışanlar, zaman zaman örgütteki dağıtım kararlarını değerlendirerek dağıtımsal adalet algılarını, zaman zaman süreçleri değerlendirerek etkileşimsel adalet algılarını, zaman zaman da yöneticileriyle veya diğer çalışanlarla ilişkilerini değerlendirerek etkileşimsel adalet algılarını yansıtmaktadırlar. Çalışanların örgütsel adalet algılarını belirleyen unsurların neler olduğu ise tam olarak anlaşılamamıştır. Bazı çalışanlar tarafından adil olarak algılanan bir durum bazı çalışanlar tarafindan adil olarak algılanmayabilir. Dolayısıyla örgütsel adaletin incelenmesi kavramın anlaşılması bakımından önem taşımaktadır. Bu çalışmada örgütsel adalet kavramı incelenmiştir.

Örgütsel özdeşleşme ise son zamanlarda yapılan çalışmalar ile araştırmacıların odak noktası olmuştur. Özdeşleşme kavramı ilk olarak sosyal kimlik teorisinden hareketle örgütsel düzeyde incelenmiştir. Sosyal kimlik teorisine göre bireylerin kendilerini ait oldukları gruplara göre tanımladığı savunulmaktadır. Bu yönüyle örgütsel anlamda özdeşleşme ise bireyin kendini örgütü ile bir görmesi olarak değerlendirilmektedir. Bireyler, örgütün başarı ve başarısızlığını kendi başarı ve başarısızlığı gibi algılamaktadır. Ben yerine daha çok biz anlayışı ile hareket eden bireylerin örgütsel olarak özdeşleştiği söylenebilir. Bu durumun hem bireyler hem de örgütler açısından incelenmesi gerekir. Dolayısıyla bu çalışmada örgütsel özdeşleşme kavramı incelenmiştir.

Literatürde ise örgütsel adalet ve örgütsel özdeşleşme ile ilgili birçok çalışma vardır. Bu çalışmalarda henüz bir fikir birliği oluşamamıştır. Nitekim adalet ve özdeşleşme kavramlarının doğası gereği karmaşık olması sürecin anlaşılmasını zorlaştırmaktadır. Bir kamu kurumu olan üniversitelerde ise akademik ve idari personelin örgütsel adalet algıları ve örgütsel özdeşleşme düzeylerinin incelenmesi kamu sektöründeki durumu yansıtacağı düşünülmektedir.

Bu bağlamda araştırmada örgütsel adalet ve örgütsel özdeşleşme arasındaki ilişkiyi incelemek amaçlanmıştır. Daha sonra cinsiyet, yaş, eğitim düzeyi, kıdem, unvan ve idari görevin olup olmaması gibi demografik değişkenlerin örgütsel adalet, örgütsel adaletin boyutları ve örgütsel özdeşleşme değişkenlerinde anlamlı bir farklılığa yol açıp açmadığını tespit etmek amaçlanmıştır. Buradan hareketle ilk olarak örgütsel adalet kavramı incelenmiş ve örgütsel özdeşleşme kavramı ele alınarak açıklanmaya çalışılmıştır. Devamında araştırma örneklemi hakkında bilgi verilmiştir. Son olarak ise araştırmanın modeli açıklanarak hipotezler test edilmiştir. Elde edilen bulgular önceki çalışmalar ile karşılaştırılarak değerlendirilmiştir.

\section{Kavramsal Çerçeve}

\section{1. Örgütsel Adalet}

Örgütlerin en stratejik unsuru olan insan kaynağı, yönetim bilimciler tarafından üzerinde önemle durulan bir unsurdur. Adalet ve yönetimi, tarih boyunca toplumların gelişmesine uygun bir zemin hazırlamış ve insanın temel ve içsel ihtiyaçlarından biri olmuştur. Bir toplumda adaletin yönetimi, örgütlerde adaletin gözetilmesine bağlıdır (Bidarian ve Jafari, 2012: 1622). Adalet kavramının örgütlerdeki rolüne vurgu yapan Greenberg, bireylerin örgütlerdeki adalet algılarını ifade eden örgütsel adalet kavramını geliştirmiştir (Hoy ve Tarter, 2004: 250). Örgütsel adalet, literatürde ilk olarak 1960'larda ve 1970'lerde araştırmacıların dikkatini üzerine 
çekmiştir. Örgütlerde meydana gelen çatışmaların çözümü, personel seçimi, iş uyuşmazlıkları ve ücret gibi adalet konusundaki endişeler farklı yaklaşımları da beraberinde getirmiştir (Greenberg, 1987: 9).

Örgütsel adalet, doğrudan işyeri ile ilgili olduğu için adaletin örgütteki rolünü tanımlamak için kullanılan bir terimdir. Başka bir ifadeyle örgütsel adalet, çalışanların işlerinde kendilerine adil davranılıp davranılmadığını belirleme ve bu belirlemelerin işle ilgili diğer değişkenleri etkileme biçimleriyle ilgilidir (Moorman, 1991: 845). Çalışanlar, örgüt tarafından kendilerine ne kadar değer verildiğinin bir göstergesi ve iş yerindeki tutum ve davranışlarını etkileyen bir unsur olduğu için örgütsel adalete önem verirler (Rupp, 2011: 73). Aslında örgütsel adalet, çalışanların tüm faaliyetlerinde, davranışlarında ve eğilimlerinde bir tür tatmindir. Bu yönüyle örgütteki düşünce ve değer yönetiminin ve aynı zamanda tüm örgütsel değer ve ilkelerin temelini oluşturan önemli bir kavram olarak görülmektedir (Choudhary ve Kumar, 2011: 19).

Genel bir ifadeyle örgütsel adalet, çalışanların karşılaştıkları muamelenin adil olma düzeyine yönelik algıları olarak tanımlanabilir (Onn ve Lung, 2014: 256). Bu anlamda örgütsel adalet, ahlaki değerlere uygunluk ve etik davranış yargılarıyla ilgilidir. Bir eylemin veya olayın adil olup olmadığına karar vermek için bireyler, bazı kriterlere göre içinde bulunduğu durumu değerlendirirler (Cropanzano vd., 2018: 2). Bireyler ve örgütler arasındaki girdi ve çıktıların oranına ilişkin bireylerin beklentisi bu kriterlerden biri olarak görülebilir. Bireylerin kendileri ve diğerleri ile ilgili olarak algıladıkları çıktıların girdilere oranı genellikle bir dereceye kadar tutarlı olmasına rağmen, göreceli olarak farklı oldukları hissedilirse bunun adaletsizlik olarak algılanması olası bir durumdur (Jang vd., 2021: 147). Örgütsel adalet, çalışanlar işyerinde haksız muamele algıladığında örgütler üzerinde etkili olan ve sonucu olumsuz duygu ve davranışlara dönüşen bir süreçtir. Haksız muamele veya adaletsizlik sadece iş performansını düşürmekle kalmaz, aynı zamanda işin kalitesini ve çalışanlar arasındaki işbirliğinin derecesini de düşürür (Fatimah vd., 2011: 115).

Literatür incelendiğinde örgütsel adalet algısının dağıtımsal, işlemsel ve etkileşimsel olmak üzere üç boyutlu bir yapıya sahip olduğu ve örgütsel adalet algısının bunların birleşiminden ortaya çıktığı görülmektedir (Najafi vd., 2011: 5244; Lönnqvist vd., 2021: 2). Örgütsel adaletin üç biçimi birbiriyle ilişkili olmasına rağmen, araştırmalar, çalışanların iş tutumlarıyla ilişkilerinde bağımsız olduklarını göstermektedir (DeConinck, 2010: 1350). Dağıtımsal adalet, kaynak dağılımının çalışanlar tarafından algılanan adaletini ifade eder. $\mathrm{Bu}$ görüş, çalışanların ortaya koydukları çabanın miktarı göz önüne alındığında, örgüt tarafından sunulan sonuçların (örneğin, performans derecelendirmeleri, ücret, terfiler) adil olup olmadığ hakkında karar verdikleri eşitlik teorisinden kaynaklanmaktadır (Blakely vd., 2005: 261). Teoriye göre çalışanlar, örgüte sundukları girdi ile elde ettiği sonuçlar arasındaki oranı diğer çalışanlar ile karşılaştırmakta ve bunun dengeli olduğunu düşündüklerinde adil muamelenin ortaya çıkacağını algılamaktadır (Sjahruddin ve Sudiro, 2013: 134).

Bir diğer bileşen ise işlemsel adalettir. Dağıtım adaleti, çalışanların işyerinde algılanan adaletsizliğe nasıl tepki vereceğini tam olarak tahmin etmede yetersiz kalmıştır. Bu nedenle, örgütsel adalet çalışmaları, odaklarını dağıtım adaletinden işlemsel, yani algılanan süreçlerin adaletine kaydırmaya başlamıştır (Chen vd., 2015: 2). İşlemsel adalet, örgüt tarafindan kullanılan sistem ve süreçlerin adil olması gerektiği konusundaki önyargıyı ifade eder. Birçok çalışan, sonuçtan bağımsız olarak dağıtım kararlarının belirlenmesinde kullanılan sistemlerin doğru, açık ve dürüst olmasını ister. Yani süreç, sonuçların kendisinden daha önemli görülür (Jameel vd., 2020: 2). Dağıtımsal adalet ve işlemsel adaletin bir uzantısı olarak ifade edilen etkileşimsel adalet ise örgütsel uygulamaların beşeri yönünü temsil etmektedir (İşcan ve Sayın, 2010: 197). Etkileşimsel adalet, örgütte kararlar alınırken ve uygulanırken bireyin karşılaştığ1 kişilerarası ilişkilere odaklanmaktır (Lance Frazier vd., 2010: 42). Etkileşimsel adalet, 
prosedürleri yürütenler veya sonuçları belirleyenler tarafindan bireylere ne derece adil davranıldığını yansıtan kişilerarası bir bileşene sahiptir ve daha çok yöneticiler ve astlar arasında meydana gelen kişisel ilişkilerden kaynaklanmaktadır (Seifert vd., 2010: 710).

\section{2. Örgütsel Özdeşleşme}

Bireyler, sosyal hayatlarında kendilerini içinde bulundukları gruplar açısından ifade etmeyi tercih ederler. Kendilerini örgütle arasındaki ilişkiye ve örgütün özelliklerine göre ifade etmesi ise grup üyeliğinin bir yönü olan örgütsel özdeşleşme ile açıklanır (Şantaş vd., 2016: 872). Örgütsel davranış, sosyal psikoloji ve iletişim alanındaki araştırmacılar, 1980'lerin sonlarından başlayarak örgütsel özdeşleşmeyi benzersiz bir yapı olarak ele almıştır. İlk olarak Ashforth ve Mael (1989), sosyal psikoloji teorilerinin örgütsel davranış araştırmalarıyla ilişkisini ele alarak örgütsel özdeşleşme kavramına dikkat çekmiştir (Riketta, 2005: 359).

Örgütsel özdeşleşmenin modern kavramsallaştırması, sosyal kimlik teorisine dayanmaktadır. Sosyal kimlik teorisi, bireyin belirli sosyal gruplara aitlik algısını ifade etmektedir. Bireyler kendilerini sosyal grupların üyeleri olarak tanımladıklarında ve bu grupların özelliklerini kendilerine atfettiklerinde ve sosyal grubun bir parçası olarak kabul ettiklerinde özdeşleşme gerçekleşir. Böylece kendilerini örgütün bir parçası olarak görürler, örgüte bağlı hissederler ve örgütsel üyeliklerinden gurur duyarlar (Yue vd., 2020: 9). Bunun yanısıra genel olarak kendilerini ve diğer bireyleri belirli bir sosyal grubun üyesi olarak ayırt etme eğilimi içindedirler. Teoriye göre bireyler, gruplar arasındaki ayrımı önemseyerek kendilerini özdeşleştirdikleri grubun gerçek veya sembolik bir üyesi olarak görürler. Buradan hareketle örgütsel özdeşleşmenin de sosyal özdeşleşmenin spesifik bir yönünü içerdiği belirtilmektedir (Tak ve Çifçioğlu, 2009: 102).

Örgütlerde özdeşleşme, çoğunlukla bir bireyin kendisi ile bir topluluk arasındaki birliği algılama derecesi olarak düşünülür. Diğer taraftan araştırmacılar, bunun sadece bir durumu değil, aynı anda meydana gelen ve birbiriyle ilişkili birden çok dinamik süreci içerdiğini ve insanların ait oldukları örgütlerle ilişkilerini sürekli olarak yeniden değerlendirip gözden geçirdiklerini giderek daha fazla kabul etmektedirler (Brown, 2017: 296). Literatür incelendiğinde örgütsel özdeşleşmenin farklı şekillerde tanımlandığı görülmektedir. Genel olarak ise birey ve örgüt arasındaki psikolojik bir bağlantıya atıfta bulunulduğu söylenebilir (Edwards ve Peccei, 2010: 17). Yapılan tanımlar arasında en bilineni ve en sık kullanılanı Mael ve Ashforth (1992) tarafindan yapılan tanımdır. Mael ve Ashforth (1992) örgütsel özdeşleşmeyi, çalışanların kendilerini örgütle bir olduğunu algılaması ve örgütün başarılarını ya da başarısızlıklarını, kendi başarıları ya da başarısızlıkları gibi içselleştirmesi olarak tanımlamıştır (Mael ve Ashforth, 1992: 103).

Örgütsel özdeşleşme, çalışanların kendilerini ait oldukları grup ve örgütler açısından düşünme eğiliminde olmaları olarak tanımlanmaktadır. Başka bir ifade ile kavram, çalışanların kendilerini örgüte göre tanımlama sürecini veya örgütün tanımı ile kendilerine yönelik tanımları arasındaki bilişsel bağlantıyı içerir (Mozes vd., 2011: 313). Dolayısıyla çalışanların karşılaşılan her koşulda örgütleriyle arasında birlik ve dayanışma duygusunu geliştirmeleri, davranış ve tutumlarıyla örgüte katkıda bulunması ve kendilerini örgütle bütünleştirmesi ve kişiselleştirmesi beklenmektedir (Turunç ve Çelik, 2010: 187). Sonuç olarak bir bireyin benliğinin örgüt üyeliğine bağlı olma düzeyi örgütsel özdeşleşmeyi yansıtmaktadır. Buna göre bireyin benliğinde örgüt üyeliği merkezi bir konuma sahipse ve diğer sosyal gruplardaki üyeliklerinden daha ön plandaysa, bireyin örgütüyle özdeşleştiği söylenebilir (Karabey ve İşcan, 2007: 232). 


\section{Araştırma}

\subsection{Araştırmanın Amacı ve Yöntemi}

$\mathrm{Bu}$ araştırmada örgütsel adalet ve örgütsel özdeşleşme arasındaki ilişkiyi incelemek amaçlanmıştır. Kırgızistan-Türkiye Manas Üniversitesi'ndeki 110 akademik ve idari personel üzerinde yapılan çalışmada, kolayda örnekleme yöntemiyle veriler toplanmıştır. Katılımcılara anket yöntemi kullanılarak form dağıtılmıştır. Araştırma 2020 yılından önce yapıldığı için etik kurul için başvuru yapılmamıştır. Araştırmaya gönüllü olan personel katılmıştır.

Araştırmada kullanılan anket formu üç bölümden oluşmaktadır. İlk olarak katılımcıların demografik özelliklerine yönelik ifadelere yer verilmiştir. İkinci bölümde Niehoff ve Moorman (1993) tarafindan geliştirilen "Örgütsel Adalet Ölçeği”" kullanılmıştır. Türkçe formu ise Serinkan ve Erdiş (2014) tarafından yapılan çalışmada yer almaktadır. Ölçek 20 ifade ve üç alt boyutu içermektedir. Ölçekteki 5 ifade dağıtımsal adaleti, 6 ifade işlemsel adaleti ve 9 ifade etkileşimsel adaleti temsil etmektedir. Üçüncü bölümde ise Mael ve Ashforth (1992) tarafindan geliştirilen ve Türkçe formu Saruhan (2017) tarafından hazırlanan "Örgütsel Özdeşleşme Ölçeği”" kullanılmıştır. Ölçek 6 ifadeden oluşan bir yapıya sahiptir. Ölçeklerde yer alan ifadeler (1) Kesinlikle katılmıyorum ile başlayan ve (5) Kesinlikle katılmıyorum şeklinde derecelendirilen 5'li Likert tipi ölçek kullanılarak hazırlanmıştır.

\subsection{Araştırmanın Modeli ve Hipotezleri}

Araştırmada örgütsel adalet ve örgütsel özdeşleşme arasındaki ilişkiyi incelemek amacıyla Şekil 1'deki model geliştirilmiştir. Modelde örgütsel adalet ve boyutları ile örgütsel özdeşleşme arasındaki ilişki gösterilmektedir. Ayrıca demografik değişkenler açısından örgütsel adalet, dağıtımsal adalet, işlemsel adalet, etkileşimsel adalet ve örgütsel özdeşleşme algılamalarındaki farklılık belirlenmeye çalışılmıştır.

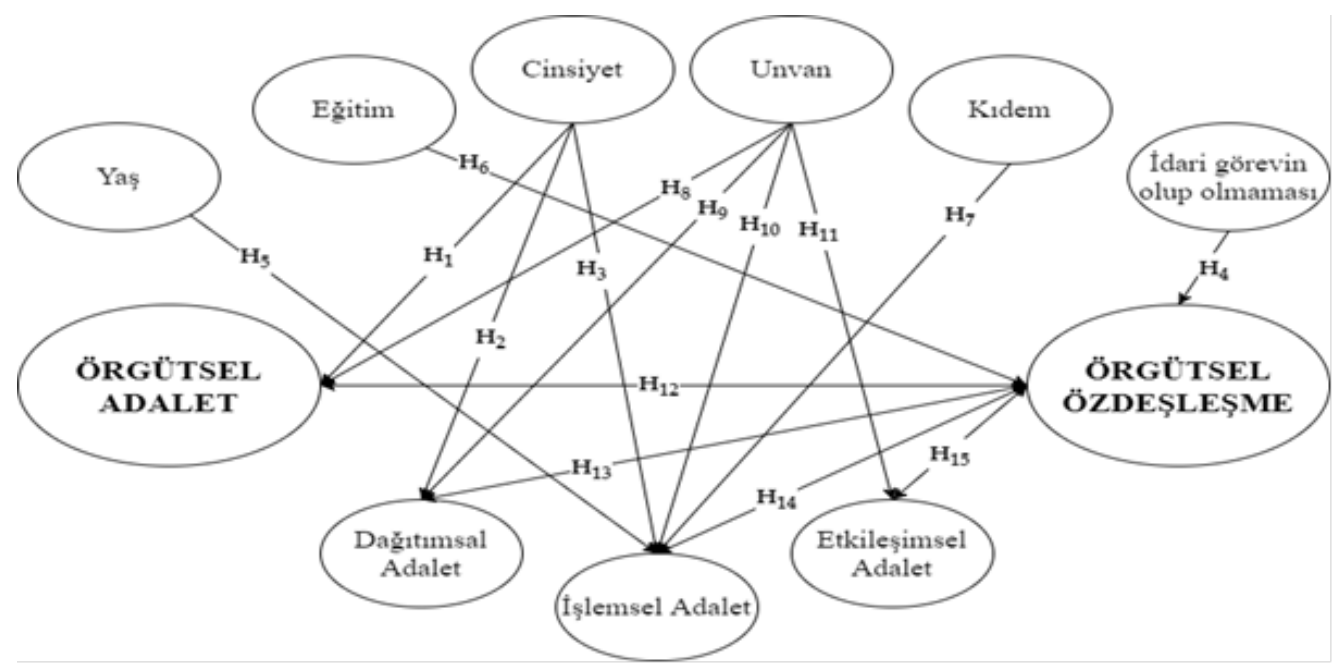

Şekil 1: Araştırmanın Modeli

Araştırmanın modeli kapsamında aşağıdaki hipotezler geliştirilmiştir.

H1: Cinsiyete göre örgütsel adalet düzeyi farklılık göstermektedir.

H2: Cinsiyete göre dağıtımsal adalet düzeyi farklılık göstermektedir.

H3: Cinsiyete göre işlemsel adalet düzeyi farklılık göstermektedir.

H4: İdari görevin olup olmamasına göre örgütsel özdeşleşme düzeyi farklılık göstermektedir. 
H5: Yaşa göre işlemsel adalet düzeyi farklılık göstermektedir.

H6: Eğitim düzeyine göre örgütsel özdeşleşme düzeyi farklılık göstermektedir.

H7: Kıdeme göre işlemsel adalet düzeyi farklılık göstermektedir.

H8: Unvana göre örgütsel adalet düzeyi farklılık göstermektedir.

H9: Unvana göre dağıtımsal adalet düzeyi farklılık göstermektedir.

H10: Unvana göre işlemsel adalet düzeyi farklılık göstermektedir.

H11: Unvana göre etkileşimsel adalet düzeyi farklılık göstermektedir.

H12: Örgütsel adalet ve örgütsel özdeşleşme arasında anlamlı bir ilişki vardır.

H13: Dağıtımsal adalet ve örgütsel özdeşleşme arasında anlamlı bir ilişki vardır.

H14: İşlemsel adalet ve örgütsel özdeşleşme arasında anlamlı bir ilişki vardır.

H15: Etkileşimsel adalet ve örgütsel özdeşleşme arasında anlamlı bir ilişki vardır.

\section{Bulgular}

\subsection{Demografik Özelliklere İlişkin Bulgular}

Tablo 1'de araştırmaya katılan akademik ve idari personelin demografik özelliklerine ilişkin bilgiler yer almaktadır.

Tablo 1. Katılımc1ların Demografik Özellikleri

\begin{tabular}{|c|c|c|c|c|c|c|c|}
\hline Değişkenler & Gruplar & $\mathbf{n}$ & $\%$ & Değişkenler & Gruplar & $\mathbf{n}$ & $\%$ \\
\hline \multirow{2}{*}{ Cinsiyet } & Erkek & 63 & 57,3 & \multirow{2}{*}{ Görevi } & Akademik Personel & 85 & 77,3 \\
\hline & Kadın & 47 & 42,7 & & İdari Personel & 25 & 22,7 \\
\hline \multirow{3}{*}{ Yaş } & 35 yaș ve altı & 37 & 33,6 & \multirow{2}{*}{ İdari görevi } & Var & 36 & 32,7 \\
\hline & $36-45$ yaş aralığ & 42 & 38,2 & & Yok & 74 & 67,3 \\
\hline & 46 yaș ve üzeri & 31 & 28,2 & \multirow{6}{*}{$\begin{array}{l}\text { Akademik } \\
\text { personelin } \\
\text { unvanları }\end{array}$} & Profesör & 20 & 18,2 \\
\hline \multirow{2}{*}{$\begin{array}{l}\text { Medeni } \\
\text { durum }\end{array}$} & Evli & 85 & 77,3 & & Doçent & 17 & 15,5 \\
\hline & Evli Değil & 25 & 22,7 & & Yardımcı Doçent & 5 & 4,5 \\
\hline \multirow{3}{*}{ Eğitim düzeyi } & Lisans & 16 & 14,5 & & Araştırma Görevlisi & 21 & 19,1 \\
\hline & Yüksek Lisans & 55 & 50,0 & & Öğretim Görevlisi & 15 & 13,6 \\
\hline & Doktora & 39 & 35,5 & & Okutman & 7 & 6,4 \\
\hline \multirow{2}{*}{ Alanı } & Sosyal Bilimler & 59 & 53,6 & \multirow{4}{*}{$\begin{array}{l}\text { İdari } \\
\text { personelin } \\
\text { unvanları }\end{array}$} & Uzman & 6 & 5,5 \\
\hline & Fen Bilimleri & 51 & 46,4 & & Şef & 4 & 3,6 \\
\hline \multirow{3}{*}{ Kıdem } & 5 y1l ve alt1 & 31 & 28,2 & & Memur & 6 & 5,5 \\
\hline & 6-10 yıl aralığında & 44 & 40,0 & & Diğer & 9 & 8,2 \\
\hline & 11 yıl ve üstü & 35 & 31,8 & & & \multicolumn{2}{|c|}{$\mathrm{n}=110$} \\
\hline
\end{tabular}

Buna göre katılımcıların \%57'3'ü erkeklerden, \%42,7'si kadınlardan oluşmaktadır. Yaşlarına bakıldığında \%33,6'sı 35 yaş ve altında, \%38,2'si 36-45 yaş aralığında ve \%28,2'si 46 yaş ve üzerinde bir yaşa sahiptir. Evli çalışanlar, katılımcıların \%77,3'ünü, evli olmayanlar 22,7 'sini temsil etmektedir. Lisans mezunu çalışanların oranı \%14,5, yüksek lisans mezunu olanların oran $1 \% 50,0$ iken doktora mezunu olanların oranı \%35,5'tir. Katılımcıların \%53,6's1 sosyal bilimler alanında, \%46,4'ü fen bilimleri alanında çalışmaktadır. Araştırmada 5 yıl ve altında kıdemli olanlar \%28,2'yi, 6-10 yıl aralığında kıdemli olanlar \%40,0’1 ve 11 y1l ve üstü kıdemli olanlar \%31,8'i oluşmaktadır. Çalışanların \%77,3'ü akademik personel, \%22,7'si idari personeldir. Bunların \%32,7'sinin idari bir görevi varken, \%67,3'ünün idari görevi yoktur. Akademik personelin unvanlarına bakıldığında \%18,2'si profesör, \%15,5'i doçent, \%4,5'i yardımcı doçent, \%19,1'i araştırma görevlisi, \%13,6'sı öğretim görevlisi ve \%6,4 okutmandır. 
İdari personelin unvanlarına bakıldığında, \%5,5'i uzman, \%3,6'sı şef, \%5,5'i memur ve \%8,2'si diğer görevlerdeki unvanlara sahiptir.

\section{2. Ölçeklerin Güvenilirliği}

Ölçeklerin güvenilirliği, Cronbach's Alpha katsayısı ile test edilerek değerlendirilmiştir. Tablo 2'de örgütsel adalet ve örgütsel özdeşleşme ölçeğinin güvenilirlik düzeyleri verilmiştir. Genellikle ölçeklerin güvenilirliği değerlendirilirken Cronbach's Alpha katsayı değeri 0-0,40 aralığında olanlar güvenilir değil, 0,41-0,60 aralığında olanlar düşük düzeyde güvenilir, 0,610,80 aralığında olanlar oldukça güvenilir, 0,81-1 aralığında olanlar yüksek düzeyde güvenilir olarak kabul edilebileceği belirtilmektedir (Üngüren, 2008: 893).

Tablo 2. Ölçeklerin Güvenilirliği

\begin{tabular}{|l|c|r|}
\hline Değişkenler & Madde Sayısı & Cronbach's Alpha \\
\hline Örgütsel Adalet & 20 & 0,75 \\
\hline Örgütsel Özdeşleşme & 5 & 0,72 \\
\hline
\end{tabular}

Araştırmada kullanılan örgütsel adalet ölçeği 20 ifadeden oluşmakta ve güvenilirlik düzeyi 0,75 olarak hesaplanmıştır. Bununla birlikte örgütsel özdeşleşme ölçeğine yönelik yapılan analizde ölçekte yer alan "Eleştirilerden rahatsız olurum" ifadesinin güvenilirlik düzeyini düşürdügü görülmüş ve ölçekten çıkarılmasına karar verilmiştir. İfade çıkarıldıktan sonra 5 ifadeden oluşan örgütsel özdeşleşme ölçeğinin 0,72 düzeyinde güvenilir olduğu görülmüştür. Böylece araştırmada kullanılan ölçeklerin belirtilen sınırlar içerisinde güvenilir oldukları söylenebilir.

\subsection{Hipotezlerin Test Edilmesi}

Araştırmanın bu bölümünde araştırmanın hipotezleri test edilmiştir. Katılımcıların demografik özelliklerinin örgütsel adalet ve boyutları ile örgütsel özdeşleşme değişkenlerinde anlamlı bir farklılığa yol açıp açmadığı test edilmiş ve değerlendirilmiştir. Araştırmada iki gruplu bağımsız değişkenler için t-testi ve ikiden fazla gruplu bağımsız değişkenler ise Anova testi ile analiz edilmiştir. Ayrıca örgütsel adalet, dağıtımsal adalet, işlemsel adalet, etkileşimsel adalet ve örgütsel özdeşleşme değişkenleri arasındaki ilişkiler korelasyon analizi ile incelenmiştir.

Tablo 3. Hipotez Testleri

\begin{tabular}{|c|c|c|c|c|c|c|c|c|c|}
\hline & Değişkenler & & (1) & (2) & (3) & (4) & (5) & $\overline{\mathrm{x}}$ & ss. \\
\hline \multirow{2}{*}{ 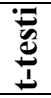 } & Cinsiyet & $\mathrm{p}$ & ,013* &, $002 *$ &, $020^{*}$ & 320 & ,734 & - & - \\
\hline & İdari görevi & $\mathrm{p}$ & 231 & 146 & 292 & ,560 &, $031 *$ & - & - \\
\hline \multirow{4}{*}{ 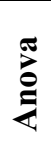 } & Yaş & $\mathrm{p}$ &, 089 & 143 &, $019 *$ & ,665 & ,756 & - & - \\
\hline & Eğitim & $\mathrm{p}$ &, 730 & ,985 & ,957 &, 512 &, $008 *$ & - & - \\
\hline & Kidem & $\mathrm{p}$ & ,429 &, 633 &, $001 *$ &, 860 & ,314 & - & - \\
\hline & Unvan & $\mathrm{p}$ &, $004 *$ & ,004* &, $018^{*}$ &, $032 *$ & ,627 & - & - \\
\hline \multirow{10}{*}{ 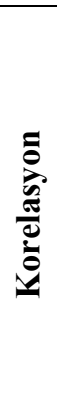 } & \multirow{2}{*}{ Örgütsel adalet (1) } & $\mathrm{r}$ & 1 &, $594 * *$ &, $767 * *$ &, $820 * *$ &, 104 & \multirow{2}{*}{3,69} & \multirow{2}{*}{,33 } \\
\hline & & $\mathrm{p}$ & - &, 000 & , 000 & , 000 & 278 & & \\
\hline & \multirow{2}{*}{ Dağıtımsal adalet (2) } & $\mathrm{r}$ &, $594 * *$ & 1 & ,398** & , $187 *$ & ,301** & \multirow{2}{*}{3,73} & \multirow{2}{*}{,41 } \\
\hline & & $\mathrm{p}$ &, 000 & - &, 000 &, 050 & ,001 & & \\
\hline & \multirow{2}{*}{ İşlemsel adalet (3) } & $\mathrm{r}$ & ,767** & ,398** & 1 &, $379 * *$ & ,056 & \multirow{2}{*}{3,67} & \multirow{2}{*}{,45 } \\
\hline & & $\mathrm{p}$ &, 000 &, 000 & - &, 000 & 560 & & \\
\hline & \multirow{2}{*}{ Etkileşimsel adalet (4) } & $\mathrm{r}$ &, $820 * *$ &, $187 *$ & ,379** & 1 &,- 023 & \multirow{2}{*}{3,67} & \multirow{2}{*}{,44 } \\
\hline & & $\mathrm{p}$ &, 000 &, 050 & ,000 & - & ,810 & & \\
\hline & \multirow{2}{*}{ Örgütsel özdeşleşme (5) } & $\mathrm{r}$ & , 104 &, $301 * *$ & ,056 &,- 023 & 1 & \multirow{2}{*}{4,30} & \multirow{2}{*}{,38 } \\
\hline & & $\mathrm{p}$ & ,278 & ,001 & 560 &, 810 & - & & \\
\hline
\end{tabular}


Yapılan t-testleri sonucunda cinsiyet değişkenine göre örgütsel adalet $(p=0,01)$, dağıtımsal adalet $(p=0,00)$ ve işlemsel adalet $(p=0,02)$ değişkenlerinde anlamlı bir farklılık olduğu görülmüsstür. Ortalama değerlere bakıldığında erkek çalışanların ortalama değerlerinin kadın çalışanlardan daha yüksek olduğu tespit edilmiştir. İdari görevin olup olmamasına göre örgütsel özdeşleşme $(\mathrm{p}=0,03)$ değişkeninde anlamlı bir farklılık söz konusudur. İdari görevi olanların ortalama değerleri, idari görevi olmayanlardan daha yüksektir. Bu sonuçlara göre H1 ve $\mathrm{H} 2$ hipotezleri ret edilemez.

Anova analizinden elde edilen sonuçlar incelendiğinde çalışanların yaşına göre işlemsel adalet $(0,02)$ değişkeninde anlamlı bir farklılık bulunmuştur. Yaş grupları arasında en yüksek ortalama değere 36-45 yaş aralığında olanlar sahiptir. Eğitim düzeyine göre örgütsel özdeşleşme $(p=0,00)$ değişkeninde anlamlı bir farklılık gözlenmiştir. Yüksek lisans mezunlarının ortalama değerinin en yüksek değer olduğu söylenebilir. Kıdem değişkenine göre işlemsel adalet $(\mathrm{p}=0,00)$ değişkeninde anlamlı bir farklılık olduğu ve en yüksek ortalamanın 610 yıl aralığında kıdeme sahip olanlara ait olduğu tespit edilmiştir. Son olarak araştırmaya katılanların unvanlarına göre örgütsel adalet $(p=0,00)$, dağıtımsal adalet $(p=0,00)$, işlemsel adalet $(p=0,02)$ ve etkileşimsel adalet $(p=0,03)$ değişkenlerinde anlamlı bir farklılık olduğu ortaya çıkmıştır. Örgütsel adalette ve etkileşimsel adalette memurların, dağıtımsal adalette okutmanların, işlemsel adalette öğretim görevlilerinin ortalama değerleri en yüksek değerler olarak görülmüştür. Dolayısıyla H3, H4, H5, H6, H7, H8, H9, H10 ve H11 hipotezleri ret edilemez.

Son olarak korelasyon analizlerine bakıldığında örgütsel adalet ve örgütsel özdeşleşme $(\mathrm{r}=, 104$ ve $\mathrm{p}>0,05)$, işlemsel adalet ve örgütsel özdeşleşme $(\mathrm{r}=, 056$ ve $\mathrm{p}>0,05)$ ile etkileşimsel adalet ve örgütsel özdeşleşme $(r=,-023$ ve $p>0,05)$ arasında anlamlı bir ilişki bulunamamıştır. Bu nedenle H12, H14 ve H15 hipotezleri ret edilmiştir. Diğer taraftan dağıtımsal adalet ve örgütsel özdeşleşme arasında pozitif yönde, anlamlı ve orta düzeyde bir ilişki tespit edilmiştir. Bu sonuca göre H13 hipotezi ret edilemez.

\section{Sonuç}

Bu çalışmada Kırgızistan-Türkiye Manas Üniversitesi'nde görev yapan 110 akademik ve idari personel üzerinde örgütsel adalet ve örgütsel özdeşleşme arasındaki ilişki incelenmiştir. Ayrıca demografik değişkenler açısından örgütsel adalet, dağıtımsal adalet, işlemsel adalet, etkileşimsel adalet ve örgütsel özdeşleşme değişkenlerinde anlamlı bir farklılık olup olmadığı test edilmiştir.

Yapılan analizler sonucunda cinsiyete göre örgütsel adalet, dağıtımsal adalet ve işlemsel adalet değişkenlerinde anlamlı bir farklılık olduğu sonucuna varılmıştır. Bu sonuçlar Şamdan ve Baskan (2019: 27) tarafindan öğretmenlerde yapılan çalışmanın sonuçları ile benzerlik göstermektedir. Çalışmada öğretmenlerin cinsiyetine göre örgütsel adalet, dağıtımsal adalet ve işlemsel adalet algılarında farklılaşmanın meydana geldiği ve erkeklerin ortalama değerlerinin kadınlardan yüksek düzeyde olduğu belirtilmiştir. Yücekaya ve Polat (2020: 1276) da bu sonuçlara öğretmenler üzerinde ulaşmıştır. Öğretmenlerin cinsiyetine göre örgütsel adalet düzeylerinde farklılık bulunmuştur. Bu çalışmadan farklı olarak kadınların erkeklerden daha yüksek bir ortalamaya sahip olduğu ortaya çıkmıştır. Kavak ve Kaygın (2018: 43) tarafından akademisyenlere yapılan çalışmada cinsiyetin dağıtımsal adaletin algılanmasında farklılıklara yol açtığı tespit edilmiştir. Bu farklılıkta erkeklerin kadınlardan daha yüksek ortalamaya sahip olduğu görülmüştür. Kurnaz ve Oruç (2019: 383) cinsiyete göre işlemsel adalette farklılık olduğunu ve erkeklerin kadınlardan daha yüksek ortalamaya sahip olduğunu ifade etmiştir. 
Dolayısıyla önceki çalışmalarda elde edilen sonuçlar bu çalışmanın sonuçlarını desteklemektedir.

Çalışmada yaş değişkeninin işlemsel adaletin algılanmasında anlamlı bir farklılık oluşturduğu ortaya çıkmıştır. Benzer bir sonuç Kavak ve Kaygın (2018: 44) tarafından elde edilmiştir. Araştırmacılar, akademisyenlerin yaş gruplarının işlemsel adaletin algılanmasında farklılıklara neden olduğunu belirtmiştir. Bu çalışmada olduğu gibi en yüksek ortalama 36-45 yaş aralığında olan personelde görülmüştür. Ayrıca Korkmaz ve Bozkurt (2018: 242) idari personelin yaşına göre işlemsel adalet algılarını incelemiş ve anlamlı bir farklılık olduğunu gözlemlemiştir. Çalışanların yaş gruplarında ise en yüksek ortalamanın 26-33 yaş aralığındaki personelden kaynaklandığını ifade etmiştir. Son olarak Şirin vd. (2019: 300) de yaş değişkenine göre işlemsel adalet boyutunda farklılık tespit etmiş ve en yüksek ortalamanın 46-50 yaş aralığında olduğunu ifade etmiştir. Dolayısıyla araştırmanın sonuçları literatürdeki çalışmalar ile tutarl1l1k göstermektedir.

Elde edilen sonuçlara göre personelin kıdemlerine göre işlemsel adalet boyutunda anlamlı bir farklılık söz konusudur. Baltacı (2019: 40) öğretmenlerin kıdemlerine göre işlemsel adalet algılarının farklılaştığını yapmış olduğu çalışmada belirtmiştir. Bu çalışmaya göre 11 yıl ve üstü k1deme sahip olanlar, diğerlerine göre daha yüksek ortalamaya sahiptir. Korkmaz ve Bozkurt (2018: 242) tarafindan yapılan çalışmada kıdem değişkeninin personelin işlemsel adalet algılarında farklılığa yol açtığı görülmüsstür. Bu farklılığın 1-4 yıl aralığında kıdemli olan personelden kaynaklığını tespit etmiştir. Günsal (2010: 192) da çalışanların kıdemlerine göre işlemsel adalet algılarının farklılık gösterdiğini ifade etmiştir. En yüksek ortalama değerin ise 9 yıl ve üzeri kıdemli çalışanlara ait olduğu hesaplanmıştır. Buradan hareketle araştırma sonuçlarının önceki çalışmaların sonuçları ile benzerlik gösterdiği söylenebilir.

Araştırmada personelin unvanlarına göre örgütsel adalet, dağıtımsal adalet, işlemsel adalet ve etkileşimsel adalet algılarında farklılık gözlenmiştir. Şirin vd. (2019: 301) bu çalışmadaki benzer sonuçlara ulaşmıştır. Yapılan çalışmada unvana göre örgütsel adaletin alt boyutları olan dağıtımsal adalet, işlemsel adalet ve etkileşimsel adalet boyutlarında anlamlı bir farklılık bulunmuştur. Ayrıca en yüksek ortalama değere profesörlerde karşılaşılmaktadır. Yine Yelboğa (2012: 177) tarafından yapılan çalışmada da benzer sonuçlar elde edilmiştir. Şahin ve Ünnü (2020: 20) dağıtımsal adaletin unvana göre farklılaştığını, Köksal (2018: 491) işlemsel adaletin unvana göre farklılaştığını ve Özsungur (2017: 2585) etkileşimsel adaletin unvana göre farklılaştığını ifade etmiştir. Dolayısıyla bu çalışmanın sonuçları önceki çalışmalar ile tutarlı görünmektedir.

Araştırmada akademik ve idari personelin idari bir görevi olup olmamasına göre özdeşleşme düzeylerinin farklılaşıp farklılaşmadığı test edilmiştir. Buna göre anlamlı bir farklılık tespit edilmiştir. Diğer taraftan çalışmaya katılan akademik ve idari personelin eğitim düzeylerine göre örgütsel özdeşleşme düzeylerinde anlamlı bir farklılık ortaya çıkmıştır. Araştırmada elde edilen bu sonuç Tokgöz ve Seymen (2013: 69) tarafından yapılan çalışmada desteklenmektedir. Araştırmacılar çalışanların eğitim düzeylerine göre örgütsel özdeşleşme düzeylerinde anlamlı bir farklılık tespit etmiştir. Diğer taraftan Cüce vd. (2013: 16) tarafından yapılan çalışmada çalışanların eğitim düzeylerine göre örgütsel özdeşleşme düzeylerinde farklılık olmadığı görülmüştür. Dolayısıyla eğitim değişkenine göre örgütsel özdeşleşmenin farklılaştığına yönelik sonuçlar önceki çalışmalar ile benzerlik gösterirken, farklı sonuçların elde edildiğini de belirtmek gerekir.

Kırgızistan-Türkiye Manas Üniversitesi'ndeki 110 akademik ve idari personeli kapsayan bu çalışmada dağıtımsal adalet ile örgütsel özdeşleşme arasındaki ilişki incelenmiş ve söz konusu değişkenler arasında istatistiksel olarak anlamlı bir ilişki bulunmuştur. Buna karşın 
örgütsel adalet, işlemsel adalet ve etkileşimsel adalet ile örgütsel özdeşleşme arasında istatistiksel olarak anlamlı bir ilişki bulunamamıştır. Olkkonen ve Lipponen (2006: 208) bir araştırma kurumunun 160 personeli üzerinde yaptığı çalışmada bu çalışmadaki gibi dağıtımsal adalet ve örgütsel özdeşleşme arasında anlamlı bir ilişki belirlemiştir. Bu çalışmaya göre işlemsel adalet ve örgütsel özdeşleşme arasında anlamlı bir söz konusu iken, etkileşimsel adalette bu çalışmadaki gibi anlamlı bir ilişki bulunamamıştır. Dai ve Qin (2016: 52) bu çalışmanın sonuçlarından farklı bir şekilde 350 çalışan üzerinde yapmış oldukları çalışmada örgütsel adalet ve örgütsel özdeşleşme arasında anlamlı bir ilişki tespit etmiştir. Yine bu çalışmadan farklı olarak Cheung ve Law (2008: 222) çeşitli hizmet kuruluşlarında görev yapan 159 personel üzerinde yaptığ 1 çalışmada işlemsel adalet ve etkileşimsel adalet ile örgütsel özdeşleşme arasında anlamlı bir ilişki bulurken, dağıtımsal adalet ile örgütsel özdeşleşme arasında anlamlı bir ilişki bulamamıştır. Dolayısıyla belirtilen çalışmalarda elde edilen sonuçlar bu çalışmanın sonuçları ile benzerlik göstermekte ve diğer taraftan farklı sonuçlar da söz konusudur. Anlaşılacağı üzere örgütsel adalet ve boyutları ile örgütsel özdeşleşme değişkenleri arasındaki ilişki farklı örneklemlerde farklı sonuçlara yol açmaktadır.

$\mathrm{Bu}$ araştırma sınırlı bir sayıdaki örneklemi kapsamaktadır. Elde edilen sonuçlar Kırgızistan-Türkiye Manas Üniversitesi'ndeki 110 akademik ve idari personeli kapsamaktadır. Dolayısıyla sonraki çalışmalarda örneklemin daha geniş bir kitleyi içermesi gerektiği tavsiye edilmektedir. Bu çalışmada akademik ve idari personel birlikte incelenmiştir. Yapılacak olan çalışmaların farklı üniversitelerde de yapılması ve bu çalışmalarda akademik ve idari personelin ayrı ayrı ele alınarak karşılaştırılması literatüre katkı sağlayacaktır.

Son olarak özellikle son zamanlarda örgütsel adalet konusunda yaşanan problemlerin hem araştırmacılar hem yöneticiler tarafından kapsamlı bir şekilde incelenmesi, nedenleri, sonuçları ve çözümleri noktasında gerekli çalışmaların yapılması ve bu çalışmaların sonuçları araştırmacılara ve yöneticilere ulaştırılması ve buna yönelik adımların atılması önem taşımaktadır. Nitekim işyerinde meydana gelen problemlerin temelinde genel olarak adalet ile ilgili problemler yatmaktadır. Örgütlerin yöneticilerini sadece kariyer geçmişlerine ya da belirli birtakım özelliklerine göre seçmemeleri, bunun yerine adil bir yönetici olmalarına odaklanması tavsiye edilmektedir. Bununla birlikte örgütteki tüm çalışanlara adil bir örgüt yapısı benimsetilmeli, buna yönelik eğitim faaliyetleri yürütülmeli, belirli aralıklarla çalışanların adalet algıları değerlendirilmelidir.

Örgütsel özdeşleşmenin birey ve örgüt açısından önemi ifade edilmiştir. Dolayısıyla örgütlerin çalışanlarının örgütleri ile özdeşleşme düzeylerine dikkat etmesi gerekmektedir. Çalışanların örgütle özdeşleşmeleri için örgütte "ben" yerine "biz" kavramı daha sıklıkla telaffuz edilmeli ve çalışanlara bu bilinç kazandırılmalıdır. Bununla birlikte grup çalışmalarının desteklenmesi çalışanların aidiyet duygularını geliştirecektir. Belirli bir gruba aitlik hisseden çalışanların kendilerini grup özelliklerine göre tanımlaması örgütsel özdeşleşmenin bir özelliğidir. Burada bir diğer önemli nokta ise çalışanların örgütün tarihsel geçmişi ve mevcut durumu hakkında bilgi sahibi olması da sağlanmalıdır. Son olarak örgüt tarafından gerçekleştirilecek olan etkinliklerin daha sıklıkla yapılması tavsiye edilmektedir. Böylece çalışanların örgütsel özdeşleşme düzeyinin artması mümkün olmaktadır. 


\section{Kaynakça}

Baltacı, A. (2019). Din kültürü ve ahlak bilgisi öğretmenlerinin örgütsel adalet algısı ve iş doyum düzeyleri arasındaki ilişki. İnönü Üniversitesi Ĕgitim Bilimleri Enstitüsü Dergisi, $6(11), 28-49$.

Bidarian, S. and Jafari, P. (2012). The relationship between organizational justice and organizational trust. Procedia-Social and Behavioral Sciences, 47, 1622-1626.

Blakely, G. L., Andrews, M. C. and Moorman, R. H. (2005). The moderating effects of equity sensitivity on the relationship between organizational justice and organizational citizenship behaviors. Journal of Business and Psychology, 20(2), 259-273.

Brown, A. D. (2017). Identity work and organizational identification. International Journal of Management Reviews, 19(3), 296-317.

Chen, S. Y., Wu, W. C., Chang, C. S., Lin, C. T., Kung, J. Y., Weng, H. C., ... and Lee, S. I. (2015). Organizational justice, trust, and identification and their effects on organizational commitment in hospital nursing staff. BMC Health Services Research, 15(1), 1-17.

Cheung, M. F. and Law, M. C. (2008). Relationships of organizational justice and organizational identification: the mediating effects of perceived organizational support in Hong Kong. Asia Pacific Business Review, 14(2), 213-231.

Choudhary, P. and Kumar, R. (2011). Impact of organizational justice on organizational effectiveness. Industrial Engineering Letters Www. Iiste. Org, 1(3), 18-24.

Cropanzano, R., Rupp, D. E., Thornton-Lugo, M. A. and Shao, R. (2018). Organizational justice and organizational. The Oxford Handbook of Organizational Citizenship Behavior, 1-59.

Cüce, H., Güney, S. ve Tayfur, Ö. (2013). Örgütsel adalet algılarının örgütsel özdeşleşme üzerindeki etkisini belirlemeye yönelik bir araştırma. Hacettepe Üniversitesi İktisadi ve İdari Bilimler Fakültesi Dergisi, 31(1), 1-30.

Dai, K. and Qin, X. (2016). Perceived organizational support and employee engagement: based on the research of organizational identification and organizational justice. Open Journal of Social Sciences, 4(12), 46-57.

DeConinck, J. B. (2010). The effect of organizational justice, perceived organizational support, and perceived supervisor support on marketing employees' level of trust. Journal of Business Research, 63(12), 1349-1355.

Edwards, M. R. and Peccei, R. (2010). Perceived organizational support, organizational identification, and employee outcomes. Journal of Personnel Psychology, 9(1), 17-26.

Fatimah, O., Amiraa, A. M. and Halim, F. W. (2011). The relationships between organizational justice, organizational citizenship behavior and job satisfaction. Pertanika J. Soc. Sci. \& Hum, 19(5), 115-121.

Greenberg, J. (1987). A taxonomy of organizational justice theories. Academy of Management Review, 12(1), 9-22.

Günsal, E. (2010). Algllanan Örgütsel Adalet İle Örgütsel Yabancılaşma Arasındaki İlişki ve Bir Araştırma (Yayımlanmamış Yüksek Lisans Tezi). Marmara Üniversitesi Sosyal Bilimler Enstitüsü. İstanbul.

Hoy, W. K. and Tarter, C. J. (2004). Organizational justice in schools: No justice without trust. International Journal of Educational Management, 18(4), 250-259.

İşcan, Ö. F. ve Sayın, U. (2010). Örgütsel adalet, iş tatmini ve örgütsel güven arasındaki ilişki. Atatürk Üniversitesi İktisadi ve İdari Bilimler Dergisi, 24(4), 195-216.

Jameel, A. S., Mahmood, Y. N. and Jwmaa, S. J. (2020). Organizational justice and organizational commitment among secondary school teachers. Cihan University-Erbil Journal of Humanities and Social Sciences, 4(1), 1-6. 
Jang, J., Lee, D. W. and Kwon, G. (2021). An analysis of the influence of organizational justice on organizational commitment. International Journal of Public Administration, 44(2), 146-154.

Karabey, C. N. ve İşcan, Ö. F. (2007). Örgütsel özdeşleşme, örgütsel imaj ve örgütsel vatandaşlık davranışı ilişkisi: Bir uygulama. Atatürk Üniversitesi Íktisadi ve Idari Bilimler Dergisi, 21(2), 231-241.

Kavak, O. ve Kaygın, E. (2018). Örgütsel adalet algısının örgütsel muhalefet davranışı üzerindeki etkisi”, Balkan and Near Eastern Journal of Social Sciences, 4(1), 33-51.

Korkmaz, H. G. ve Bozkurt, S. (2018). Örgütsel adalet ile tükenmişlik arasındaki ilişkinin demografik değişkenler bağlamında incelenmesi ve hastane çalışanlarına yönelik bir araştırma. Uluslararası İktisadi ve İdari Íncelemeler Dergisi, 20, 233-252.

Köksal, K. (2018). Örgüt kültürünün örgütsel adalet algısına etkisinde etik ilkelere ilişkin algıların aracılık rolü. Uluslararası Yönetim İktisat ve İsletme Dergisi, 14(2), 479-504.

Kurnaz, İ. P. ve Oruç, İ. (2019). Örgütsel adalet ve iş tatmini arasındaki ilişkinin incelenmesi üzerine uygulamalı bir araştırma. Kırklareli Üniversitesi Sosyal Bilimler Dergisi, 3(3), 375-390.

Lance Frazier, M., Johnson, P. D., Gavin, M., Gooty, J. and Bradley Snow, D. (2010). Organizational justice, trustworthiness, and trust: A multifoci examination. Group \& Organization Management, 35(1), 39-76.

Lönnqvist, K., Flinkman, M., Vehviläinen-Julkunen, K. and Elovainio, M. (2021). Organizational justice among registered nurses: A scoping review. International Journal of Nursing Practice, 27(3), 1-13.

Mael, F. and Ashforth, B. E. (1992). Alumni and their alma mater: A partial test of the reformulated model of organizational identification. Journal of Organizational Behavior, 13(2), 103-123.

Moorman, R. H. (1991). Relationship between organizational justice and organizational citizenship behaviors: Do fairness perceptions influence employee citizenship?. Journal of Applied Psychology, 76(6), 845-855.

Mozes, M., Josman, Z. and Yaniv, E. (2011). Corporate social responsibility organizational identification and motivation. Social Responsibility Journal, 7(2), 310-325.

Najafi, S., Noruzy, A., Azar, H. K., Nazari-Shirkouhi, S. and Dalv, M. R. (2011). Investigating the relationship between organizational justice, psychological empowerment, job satisfaction, organizational commitment and organizational citizenship behavior: An empirical model. African Journal of Business Management, 5(13), 5241-5248.

Niehoff, B. P. and Moorman, R. H. (1993). Justice as a mediator of the relationship between methods of monitoring and organizational citizenship behaviour. Academy of Management Journal, 36(3), 527-556.

Olkkonen, M. E. ve Lipponen, J. (2006). Relationships between organizational justice, identification with organization and work unit, and group-related outcomes. Organizational Behavior and Human Decision Processes, 100(2), 202-215.

Onn, C. Y. and Lung, C. K. (2014). Supervisory support, organizational justice and perceived organizational support: A review and research agenda. Information Management and Business Review, 6(5), 255-260.

Özsungur, F. (2017). İnsan kaynakları yöneticilerinin örgütsel adalet algıları üzerine ampirik bir çalışma. Itobiad: Journal of the Human \& Social Science Researches, 6(5), 25742593.

Riketta, M. (2005). Organizational identification: A meta-analysis. Journal of Vocational Behavior, 66(2), 358-384.

Rupp, E. D. (2011). An employee-centered model of organizational justice and social responsibility. Organizational Psychology Review, 1(1), 72-94. 
Saruhan, S. (2017). Örgütsel sosyalleşmenin örgütsel özdeşleşme üzerindeki etkisi (Yayımlanmamış Yüksek Lisans Tezi). Kırıkkale Üniversitesi Sosyal Bilimler Enstitüsü. Kirıkkale.

Seifert, D. L., Sweeney, J. T., Joireman, J. and Thornton, J. M. (2010). The influence of organizational justice on accountant whistleblowing. Accounting, Organizations and Society, 35(7), 707-717.

Serinkan, C. ve Erdiş, Y. Ü. (2014). Dönüşümcü Liderlik Bağlamında Örgütsel Vatandaşlık ve Örgütsel Adalet. Nobel Yayınları.

Sjahruddin, H. and Sudiro, A. A. (2013). Organizational justice, organizational commitment and trust in manager as predictor of organizational citizenship behaviour. Interdiciplinary J. of contemporary Res. Bus.(IJCRB), 4(12), 133-141.

Şahin, S. ve Ünnü, N. A. A. (2020). Örgütsel adalet ile bağlılık kavramlarının doğası ve ilişkisi: sağlık sektörü bağlamında bir araştırma. Ankara Üniversitesi SBF Dergisi, 1-36.

Şamdan, T. ve Baskan, G. A. (2019). Öğretmenlerin algılarına göre örgütsel adalet ve örgütsel sinizm arasındaki ilişkinin incelenmesi. Pamukkale Üniversitesi Ĕ̈itim Fakültesi Dergisi, 47, 17-40.

Şantaş, F., Uğurluoğlu, Ö., Kandemir, A. ve Çelik, Y. (2016). Sağlık çalışanlarında örgütsel sinizm, iş performansı ve örgütsel özdeşleşme düzeyleri arasındaki ilişkilerin incelenmesi. Gazi Üniversitesi İktisadi ve İdari Bilimler Fakültesi Dergisi, 18(3), 867886.

Şirin, Y. E., Aydın, Ö., Öz, G. ve Şirin, T. (2019). Beden eğitimi ve spor yüksekokulu öğretim elemanlarının örgütsel adalet ve örgütsel sinizm algılamalarının incelenmesi. Electronic Turkish Studies, 14(1), 291-306.

Tak, B. ve Çiftçioğlu, B. A. (2009). Algılanan örgütsel prestij ile örgütsel bağl1lık ve örgütsel özdeşleşme arasındaki ilişkilerin incelenmesine yönelik bir araştırma. Akdeniz IİBF Dergisi, 9(18), 100-116.

Tokgöz, E. ve Seymen, O. A. (2013). Örgütsel güven, örgütsel özdeşleşme ve örgütsel vatandaşlık davranışı arasındaki ilişki: Bir devlet hastanesinde araştırma. Öneri Dergisi, 10(39), 61-76.

Turunç, Ö. ve Çelik, M. (2010). Çalışanların algıladıkları örgütsel destek ve iş stresinin örgütsel özdeşleşme ve iş performansına etkisi. Yönetim ve Ekonomi: Celal Bayar Üniversitesi İktisadi ve İdari Bilimler Fakültesi Dergisi, 17(2), 183-206.

Üngüren, E. (2008). Örgütsel çatışma yönetimi üzerine konaklama işletmelerinde bir araştırma. Uluslararası Sosyal Araştırmalar Dergisi, 1(5), 880-909.

Yelboğa, A. (2012). Örgütsel adalet ile iş doyumu ilişkisi: Ampirik bir çalışma. Ege Akademik Baklş, 12(2), 171-182.

Yue, C. A., Men, L. R. and Ferguson, M. A. (2021). Examining the effects of internal communication and emotional culture on employees' organizational identification. International Journal of Business Communication, 58(2), 169-195.

Yücekaya, P. ve Polat, D. D. (2020). Örgüt kültürü, örgütsel adalet ve iş tatmini ilişkisi üzerine bir araştırma. İşletme Araştırmaları Dergisi, 12(2), 1267-1284. 